Research Paper

\title{
Orofacial Manifestations and Temporomandibular Disorders of Sjögren Syndrome: An Observational Study
}

\begin{abstract}
Vito Crincoli ${ }^{1 凶}$, Mariasevera Di Comite ${ }^{2}$, Mariateresa Guerrieri ${ }^{1}$, Rossana Patricia Rotolo ${ }^{1}$, Luisa
\end{abstract}

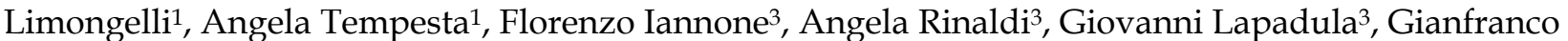
Favia $^{1}$

1. Interdisciplinary Department of Medicine, University of Bari, Italy.

2. Department of Basic Medical Sciences, Neurosciences and Sensory Organs, University of Bari, Italy.

3. Department of Emergency and Organ Transplantation, University of Bari, Italy.

$\triangle$ Corresponding author: Prof. Vito Crincoli, Interdisciplinary Department of Medicine, Piazza Giulio Cesare 11, 70124, Bari, Italy. Phone: 00390805478051 Fax: 00390805478743 E-mail: vito.crincoli@uniba.it

(C) Ivyspring International Publisher. This is an open access article distributed under the terms of the Creative Commons Attribution (CC BY-NC) license (https://creativecommons.org/licenses/by-nc/4.0/). See http://ivyspring.com/terms for full terms and conditions.

Received: 2017.09.27; Accepted: 2017.12.19; Published: 2018.03.08

\begin{abstract}
AIMS: Sjögren Syndrome is a disorder involving oral tissues, with xerostomia, dysgeusia, dysphagia, tooth decay, gingivitis, angular cheilitis and glossitis. Temporomandibular disorders are a generic term referred to clinical conditions involving the jaw muscles and temporomandibular joint. The aim of this study was to investigate the prevalence of oral manifestations and temporomandibular disorders (TMD) in Sjögren Syndrome (SS) patients compared with healthy people.
\end{abstract}

METHODS: The study group included 72 SS patients ( 2 men, 70 women) diagnosed according to the American-European Consensus Group (AECG) Criteria. A randomly selected group of 72 patients, matched by sex and age, served as control group. The examination for TMD signs and symptoms was based on the standardized Research Diagnostic Criteria for Temporomandibular Disorders (RDC/TMD) through a questionnaire and clinical examination.

RESULTS: SS patients complained more frequently $(95.8 \%)$ of oral symptoms (xerostomia, dysgeusia, dysphagia) than controls $(22.2 \%)\left(x^{2}=80.66 p<0.001\right)$. TMD symptoms (muscle pain on chewing, difficulty in mouth opening, arthralgia, headaches, tinnitus) were complained by $91.7 \%$ of SS patients and by $84.7 \%$ of controls $\left(X^{2}=1,667 p=0,196\right)$. At the clinical examination, $91,7 \%$ of SS had at least one oral sign respect to $75 \%$ of controls. The salivary flow measurements showed high statistical significance between the two groups (Unpaired test, $p<0,0001$ ). Myofascial pain (caused by muscular contracture) was significantly higher in the study group than in the control one ( $p \leq$ $0,05)$. Furthermore $18,05 \%$ of SS patients showed deflection versus $5,5 \%$ of controls $\left(X^{2}=5,402\right.$ $p=0,020$ ).

CONCLUSIONS: Sjögren's Syndrome seems to play a role in temporomandibular joint disorders.

Key words: Sjögren's Syndrome, oral manifestation, temporomandibular disorders, RDC/TMD.

\section{Introduction}

Sjögren's syndrome (SS) is a chronic, autoimmune, inflammatory disease of the exocrine glands.

There are two clinical forms: primary SS, a systemic disorder characterized by lymphocytic infiltration of exocrine glands [1] in which also extraglandular manifestations can be present, and secondary SS, in association with other autoimmune disorders, such as rheumatoid arthritis, systemic lupus erythematosus, or progressive systemic sclerosis [2].

Critical reviews estimate a variable prevalence 
from 0.35 (95\% CI, $0.17-0.65)$ up to 3.59 (95\% CI, 2.43-5.08) [3] in according to Preliminary European Criteria and from 0.05 (95\% CI, 0.048-0.052) to 0.6 (95\% CI, 0.24-1.39) according to the AmericanEuropean Consensus Group (AECG) Criteria [4]. Women are more affected than men, with a ratio of 9:1 [5] and a mean age of incidence approximately estimated between 40 and 50 years [6].

Although the etiology is still unclear, several factors have been postulated to explain the pathogenesis of the disease, such as genetic, hormonal and infectious agents. About genetic factors, population studies reveal MHC genes as critical contributors to the pathogenesis, especially those which encode HLA-DR and HLA-DQ antigens [7].

The immune disorder leads to a progressive lymphocytic infiltration of the salivary and lacrimal glands, with T helper lymphocyte (CD4+ and CD8+), polyclonal B lymphocyte activation and autoantibody production, especially antinuclear antibodies (ANA), rheumatoid factor (RF), and autoantibodies to SS-A (Ro) or SS-B (la) antigens [8], whose increase is considered the principal hematologic feature.

In addition, circulating organ- and non-organspecific autoantibodies can be present [9].

In this context, the inflammatory cells play a major role in the pathogenesis, attacking the epithelial cells [10].

Oral manifestations are due to salivary glands hypofunction, with a reduction in salivary flow (xerostomia), and a qualitative change in salivary composition [11]. Consequently, SS patients can show dental erosion and increased risk of developing tooth caries, gingivitis, periodontal disease, fungal infections especially with Candida species [12], dysgeusia, exfoliative or angular cheilitis [13], and glossitis with hyperemic and smooth tongue because of loss of papillae.

Although dry eyes (xerophthalmia) and xerostomia [14] are the most typical signs and symptoms, Sjogren's syndrome may also cause lymphocytic infiltration and immune-complex deposition in extraglandular sites, so the pathology is characterized by a systemic involvement of several organs and systems (skin, vaginal mucosa, respiratory and gastrointestinal tract, kidneys, lungs, peripheral nervous system, muscles, skeleton). SS patients can show palpable purpura, mixed cryoglobulinemia, Raynaud disease, dry nose and dry cough [15], tubular dysfunction, peripheral neuropathy, that can manifest itself like abnormal vibratory sensation, impaired position sense, paresthesias, and weakness [16]. Moreover, the development of lymphoproliferative disorders seems to be higher than those detectable in patients with other autoimmune disorders [17].

Among the most common symptoms, fatigue and generalized pain represent an important cause of impaired quality of life [18] and these pains could indicate the presence of fibromyalgia syndrome (FMS), that seems to be present in approximately $20 \%$ of patients with SS [19].

Musculoskeletal symptoms occur with a frequency range of $15-90 \%$ [20]. The distribution of joint pain is symmetrical in arthralgia, while in arthritis has an asymmetric presentation [19]. The most frequent joints involved are hands, wrists, ankles and feet [21], but also temporomandibular joint (TMJ) may be involved.

There are limited studies regarding TMJ involvement in patients with SS, so the relationship between SS and TMJ dysfunction is unclear [22].

The aim of this study was to evaluate the prevalence of temporomandibular disorders (TMD), symptoms and signs, and oral manifestations in SS patients compared with a healthy control group.

\section{Materials and Methods}

This clinical observational study was performed between June 2016 and April 2017 at the School of Dentistry and the Department of Rheumatology, University of Bari, Italy, in accordance with the provisions of the Declaration of Helsinki. Ethical approval and informed consent from each human subject were obtained.

Seventy-two patients (2 men, 70 women) with SS, diagnosed according to American-European Consensus Group (AECG) Criteria, were enrolled in the study group. A control group of 72 patients, matched by sex and age, was randomly selected among those presenting at the Dental Clinic.

Inclusion criteria were age over 18 years and European origins. Exclusion criteria were previous facial trauma, head, oral or neck neoplasia, maxillofacial surgery.

The ages of the patients ranged between 21 and 82 years old, with a mean age of $56.06(\mathrm{DS}=12,19)$ years in the SS group, and 55,32 (DS=12,17) years in the controls. Patients' drugs were recorded.

The TMD were assessed following the standardized Research Diagnostic Criteria for Temporomandibular Disorders (RDC/TMD) [23]. Symptoms and signs of both groups were valued by a single practitioner through an anamnestic questionnaire and clinical examination.

\section{PATIENTS HISTORY}

\section{Oral Symptoms}

Through a questionnaire, patients recorded the presence or the absence of the following diseases: 
Xerostomia: defined as the subjective complaint of dry mouth [24] associated to discomfort in activities such as eating, speaking, swallowing and wearing dentures. The diagnosis of xerostomia and salivary gland hypofunction requires a thorough medical history.

In fact, hyposalivation is a result of several conditions, including dehydration, denervation, trauma, chronic immune and non immune mediated inflammation of the salivary glands, head and neck irradiation therapy, psychologic factors, and medications such as anticoagulants, antidepressants, antihypertensives, antiretrovirals, hypoglycemics, levothyroxine, multivitamins and supplements, non-steroidal anti-inflammatory drugs, and steroid inhalers [25]. It occurs when basal salivary flow falls below 0.3-0.4 $\mathrm{mL} / \mathrm{min}$ [26]. A diagnosis of hyposalivation is made when unstimulated salivary flow rate is $\leq 0.1 \mathrm{~mL} / \mathrm{min}[27,28]$. In this study the test was conducted asking the patient to spit saliva, accumulated in the floor of the mouth, in a graduated tube every 60 seconds. The collection period lasted 5 minutes.

Dysgeusia: is defined as the subjective inadequate or wrong taste perception. Dysgeusia was reported when subjects experience bitter, sour, or metallic flavors [29].

Dysphagia: the symptom of difficulty in swallowing. It may be complained by the patient as a sensation of difficulty in the passage of solids from the mouth to the esophagus, probably due to bad training of the bolus, as a result of the reduction in salivary flow.

\section{TMD Symptoms}

All complaints reported by patients were collected as categorical data. They include: pain in masticatory muscles during mandibular functions, neck and shoulders stiffness, TMJ arthralgia, a feeling of locked during opening/closing mouth, temporal headaches [30, 31]. Other less common involvements are dizziness, earache and tinnitus [32]. Patients were also asked how much the pain was serious according their perception (VAS scale) and if symptoms had occurred periodically since the disease was diagnosed.

\section{CLINICAL EXAMINATION}

Myofascial pain (MP): if palpated, healthy muscles do not cause pain; on the contrary, if the muscles are contracted or inflamed, the compression elicits myalgia [33]. Palpation was carried out applying a firm pressure on the muscles.

The following masticatory muscles were palpated bilaterally: anterior, medial, and posterior temporalis muscles, masseter muscle, medial pterygoid muscle, lateral pterygoid muscle with its superior and inferior head, digastric (anterior and posterior belly) muscle, mylohyoid and sternocleidomastoid muscles.

\section{Oral Signs}

Tooth decay: presence of caries with demineralization in cervical, incisal, or in cusp tips.

Gingivitis and periodontal changes: inflamed gums appear red and swollen, often bloody. Periodontal disease can lead to gingival recession and dental loss.

Angular cheilitis: is characterized by erythema, ulcerations, flaking of the labial and sting. The buccal opening is limited and painful.

Glossitis: inflammation of the lingual mucosa, with loss of filiform papillae.

\section{TMD Signs}

TMJ sounds (TMJs):

They were estimated by palpation on each side separately during mandible movement.

Clicking is considered a single noise, sharp and short-lived, while crepitation is a multiple noise, gravel-like, [34] described as the gears of a cogwheel.

\section{Bruxism (BRUX):}

It's a particular mandibular movement characterized by clenching, grinding of the teeth and movement in various directions. It may occur during sleep or when awake [35]. Bruxism becomes pathological when it brings to myalgia (induced by prolonged vasoconstriction and accumulation of catabolites in the muscle tissue), wear facets, that alter the normal occlusal plane, and joint pain [36].

\section{Opening derangement (OD):}

In a healthy masticatory system, the movement of the jaw in the opening path is straight. The alterations in the course of the opening have been classified as:

deviation: any shift of the jaw from the midline during opening that disappears continuing the opening (return to the midline);

deflection: any shift of the mandibular midline that becomes greater with opening and does not disappear in maximum opening [37].

\section{Restricted movements (RM):}

Reduced opening: in a healthy system, the mouth opens between 53 and $58 \mathrm{~mm}$. Taking into account overbite [38], a mandibular movement is considered restricted when the distance between the incisal edge of the maxillary and mandibular incisors is lower than $40 \mathrm{~mm}$. 
Right and left lateral shifts: were recorded when the distance was from upper to lower midline was < $8 \mathrm{~mm}$.

Mandibular protrusion: was recorded when lower than $7 \mathrm{~mm}$ [39].

Endfeel: was evaluated by placing the fingers between patient's upper and lower teeth and applying a gentle but steady force in an attempt to passively increase the incisal distance.

\section{Statistical Analysis}

Categorical data were expressed as number and percentage and comparisons between SS and controls were performed using chi-squared $\left(\chi^{2}\right)$ or Fisher exact tests. Quantitative data were presented as mean and Standard Deviation (SD) and the comparisons among two group were valued by means of Student's T test for unpaired samples. In all comparisons, a $p$ value $\leq$ 0.05 was considered statistically significant. Statistical analyses were performed by using GraphPad Prism 6.0 .

\section{Results}

\section{Characteristic of SS Patients and Controls}

Patients' age ranged between 21 and 82 years, 97.2\% were female and $2.7 \%$ were male in both groups. The two groups, matched for age and sex, resulted similar for sociodemographic aspects. Among study and control groups, housewives were prominent (Table 1).

Table 1. Sociodemographic characteristics of SS patients and controls.

\begin{tabular}{|c|c|c|c|c|}
\hline \multicolumn{2}{|c|}{$\begin{array}{l}\text { Sociodemographic SS } \\
\text { Characteristics }\end{array}$} & Controls & \multirow[t]{2}{*}{ Test } & $p$ Value \\
\hline Age, mean $\pm \mathrm{SD}$ & $56,06 \pm 12,19$ & $55,32 \pm 12,17$ & & \\
\hline \multicolumn{5}{|l|}{ Sex, n (\%) } \\
\hline male & $2(2,8 \%)$ & $2(2,8 \%)$ & & \\
\hline female & $70(97,2 \%)$ & $70(97,2 \%)$ & & \\
\hline \multicolumn{5}{|c|}{ Educational degree, n (\%) } \\
\hline primary & $23(31,9 \%)$ & $17(23,6 \%)$ & $x^{2}=$ & 0,081 \\
\hline secondary & $22(30,6 \%)$ & $16(22,2 \%)$ & 6,7265 & \\
\hline high & $24(33,3 \%)$ & $28(38,9 \%)$ & & \\
\hline academic & $3(4,2 \%)$ & $11(15,3 \%)$ & & \\
\hline \multicolumn{5}{|l|}{ Occupation, n (\%) } \\
\hline housewife & $37(51,4 \%) 29$ & $29(40,3 \%)$ & $\chi^{2}=8,458$ & 0,133 \\
\hline office worker & $7(9,7 \%)$ & $3(4,2 \%)$ & & \\
\hline retired & $8(11,1 \%)$ & $9(12,5 \%)$ & & \\
\hline self employed & $6(8,3 \%)$ & $6(8,3 \%)$ & & \\
\hline public employed & $11(15,3 \%)$ & $24(33,3 \%)$ & & \\
\hline not employed & $3(4,2 \%)$ & $1(1,4 \%)$ & & \\
\hline \multicolumn{5}{|c|}{ Marital status, n (\%) } \\
\hline married & $56(77,8 \%)$ & $52(72,2 \%)$ & $\chi^{2}=4,507$ & 0,212 \\
\hline widower & $5(6,9 \%)$ & $8(11,1 \%)$ & & \\
\hline single & $5(6,9 \%)$ & $10(13,9 \%)$ & & \\
\hline divorced & $6(8,3 \%)$ & $2(2,8 \%)$ & & \\
\hline
\end{tabular}

The prevalent form of disease was the primary one, found in the $95.8 \%$ of SS patients $(4.2 \%$ had the secondary form), the age at diagnosis varied between 19 and 79 years (mean $=51,6$ years, $S D=12.3$ ) with a disease mean duration of 4,5 years $(\mathrm{SD}=4.9) ; 66,7 \%$ of patients had the pathology for less than 5 years.

Clinical characteristics of SS patients and controls are reported in Table 2.

The principal drugs for SS patients and controls are reported in Table 3.

Table 2. Clinical characteristics of SS patients and controls.

\begin{tabular}{|c|c|c|c|c|}
\hline $\begin{array}{l}\text { Clinical } \\
\text { Characteristics }\end{array}$ & SS & Controls & Test & $p$ Value \\
\hline Thyroid disease & $22(30,6 \%)$ & $10(13,9 \%)$ & $x^{2}=5,786$ & 0.016 \\
\hline $\begin{array}{l}\text { Arthromyalgia / } \\
\text { polyarticular } \\
\text { arthritis }\end{array}$ & $14(19,4 \%)$ & $3(4,2 \%)$ & $X^{2}=8,070$ & 0.004 \\
\hline Esophageal disease & $10(13,9 \%)$ & $1(1,4 \%)$ & $X^{2}=7,973$ & 0.005 \\
\hline Gastritis & $14(19,4 \%)$ & 0 & $X^{2}=15,507$ & $<0.001$ \\
\hline $\begin{array}{l}\text { Interstitial lung } \\
\text { disease }\end{array}$ & $6(8,3 \%)$ & 0 & $\begin{array}{l}\text { Fisher exact } \\
\text { test }\end{array}$ & 0.014 \\
\hline Kidney disease & $7(9,7 \%)$ & $1(1,4 \%)$ & $\begin{array}{l}\text { Fisher exact } \\
\text { test }\end{array}$ & 0.031 \\
\hline Liver disease & $7(9,7 \%)$ & 0 & $\begin{array}{l}\text { Fisher exact } \\
\text { test }\end{array}$ & 0.006 \\
\hline Neuropathy & $9(12,5 \%)$ & $1(1,4 \%)$ & $X^{2}=6,878$ & 0.009 \\
\hline Vasculitis & $6(8,3 \%)$ & 0 & $\begin{array}{l}\text { Fisher exact } \\
\text { test }\end{array}$ & 0.014 \\
\hline Raynaud disease & $25(34,7 \%)$ & 0 & $X^{2}=30,252$ & $<0.001$ \\
\hline $\begin{array}{l}\text { Lymphoproliferative } \\
\text { disorders }\end{array}$ & $2(2,8 \%)$ & 0 & $\begin{array}{l}\text { Fisher exact } \\
\text { test }\end{array}$ & 0.248 \\
\hline Blood disorders & $9(12,5 \%)$ & $1(1,4 \%)$ & $X^{2}=6,878$ & 0.009 \\
\hline Osteoporosis & $22(30,6 \%)$ & $1(1,4 \%)$ & $X^{2}=22,818$ & $<0.001$ \\
\hline Hypovitaminosis & $27(37,5 \%)$ & $1(1,4 \%)$ & $X^{2}=29,970$ & $<0.001$ \\
\hline Hypertension & $24(33,3 \%)$ & $19(26,4 \%)$ & $X^{2}=0,829$ & 0.362 \\
\hline Diabetes mellitus & $5(6,9 \%)$ & $4(5,6 \%)$ & $\begin{array}{l}\text { Fisher exact } \\
\text { test }\end{array}$ & 00.05 \\
\hline Cardiopathy & $14(19,4 \%)$ & $5(6,9 \%)$ & $X^{2} 4,912$ & 0.027 \\
\hline Dyslipidemia & $10(13,9 \%)$ & $3(4,2 \%)$ & $\mathrm{X}^{2} 4,143$ & 0.042 \\
\hline
\end{tabular}

The proportion of patients with joint involvement was higher in the SS patients than in the controls; frequency's distributions between the groups is also significantly different $\left(\chi^{2}=14,3 ; p<\right.$ 0,001 ) (Table 4).

\section{SS Oral symptoms}

Overall, patients complained the presence or the absence of oral symptoms through a questionnaire. These were more frequent in the study group than in the control one. Sixty-nine SS $(95,8 \%)$ reported one or more oral symptoms compared to 16 of the controls $(22,2 \%)$. A statistically significant difference between two groups was found for all reported findings.

\section{TMD Symptoms}

The valuation of TMDs showed that $91,7 \%$ of the patients with SS and $84,7 \%$ of the controls complained one or more symptoms. Statistically significant differences were found for all subjective complaints, except for temporal headaches $(p=0,494)$ (Table 6). 
Table 3. SS patients and controls' drugs.

\begin{tabular}{|c|c|c|c|c|}
\hline Drugs & SS & Controls & Test & $p$ Value \\
\hline Opioids & $2(2.8 \%)$ & 0 & $\begin{array}{l}\text { Fisher } \\
\text { exact test }\end{array}$ & 0.248 \\
\hline Antidepressants & $3(4.2 \%)$ & $2(2.8 \%)$ & $\begin{array}{l}\text { Fisher } \\
\text { exact test }\end{array}$ & 0.5 \\
\hline Anti-diabetic drugs & $4(5.6 \%)$ & $4(5.6 \%)$ & $\begin{array}{l}\text { Fisher } \\
\text { exact test }\end{array}$ & 0.641 \\
\hline Antihypertensives & $26(36.1 \%)$ & $16(22.2 \%)$ & $\begin{array}{l}\text { Fisher } \\
\text { exact test }\end{array}$ & 0.049 \\
\hline Acetylsalicylic acid & $9(12.5 \%)$ & $3(4.2 \%)$ & $\mathrm{X}^{2}=3.273$ & 0.071 \\
\hline benzodiazepines & $4(5.6 \%)$ & 0 & $\begin{array}{l}\text { Fisher } \\
\text { exact test }\end{array}$ & 0.059 \\
\hline Bisphosphonates & $10(13.9 \%)$ & $1(1.4 \%)$ & $X^{2}=7.973$ & 0.005 \\
\hline Cholecalciferol & $57(79.2 \%)$ & $4(5.6 \%)$ & $X^{2}=79.893$ & $<0,001$ \\
\hline Corticosteroids & $50(69.4 \%)$ & 0 & $X^{2}=76.596$ & $<0.001$ \\
\hline $\begin{array}{l}\text { Nonsteroidal } \\
\text { anti-Inflammatory drugs }\end{array}$ & $6(8.3 \%)$ & $1(1.4 \%)$ & $\begin{array}{l}\text { Fisher } \\
\text { exact test }\end{array}$ & 0.057 \\
\hline Biotechnological drugs & $8(11.1 \%)$ & 0 & $\begin{array}{l}\text { Fisher } \\
\text { exact test }\end{array}$ & 0.003 \\
\hline Hydroxychloroquine & $29(40.3 \%)$ & 0 & $X^{2}=36.313$ & $<0.001$ \\
\hline $\begin{array}{l}\text { Immunosuppressing } \\
\text { drugs }\end{array}$ & $1(1,4 \%)$ & 0 & $\begin{array}{l}\text { Fisher } \\
\text { exact test }\end{array}$ & 0.5 \\
\hline Antacids & $44(61.1 \%)$ & $3(4.2 \%)$ & $X^{2}=53.096$ & $<0.001$ \\
\hline Levothyroxine & $15(20.8 \%)$ & $8(11.1 \%)$ & $X^{2}=2.535$ & 0.112 \\
\hline Methotrexate & $23(31.9 \%)$ & 0 & $\mathrm{X}^{2}=27.372$ & $<0.001$ \\
\hline Muscle relaxants & $11(15.3 \%)$ & 0 & $X^{2}=11.909$ & $<0.001$ \\
\hline Pilocarpine & $21(29.2 \%)$ & 0 & $X^{2}=24.585$ & $<0.001$ \\
\hline Statins and fibrates & $7(9.7 \%)$ & $4(5.6 \%)$ & $\mathrm{X}^{2}=0.886$ & 0.347 \\
\hline Sulfasalazine & $3(4.2 \%)$ & 0 & $\begin{array}{l}\text { Fisher } \\
\text { exact test }\end{array}$ & 0.123 \\
\hline Topical treatment & $36(50.0 \%)$ & 0 & $X^{2}=48.00$ & $<0.001$ \\
\hline
\end{tabular}

Table 4. Joint involvement in SS patients and controls.

\begin{tabular}{lllll}
\hline Joint involvement & SS & Controls & Test & $p$ Value \\
\hline & & & & \\
\hline
\end{tabular}

Table 5. Subjective complaints of oral discomfort in SS and controls.

\begin{tabular}{lllll}
\hline Oral symptoms & SS & Controls & Test & $p$ Value \\
\hline Xerostomia & $66(91,67 \%)$ & $14(19,44 \%)$ & $\mathrm{X}^{2}=76,05$ & $<0,001$ \\
Dysgeusia & $23(31,94 \%)$ & $3(4,17 \%)$ & $\mathrm{X}^{2}=18,774$ & $<0,001$ \\
Dysphagia & $10(14,1 \%)$ & 0 & Fisher exact test & $<0,001$ \\
\hline
\end{tabular}

Table 6. TMD symptoms in SS patients and controls

\begin{tabular}{lllll}
\hline TMD symptoms & SS & Controls & $\mathbf{X}^{2}$ & $p$ Value \\
\hline $\begin{array}{l}\text { Masticatory } \\
\text { muscle pain }\end{array}$ & $20(27,7 \%)$ & $6(8,3 \%)$ & 9,199 & 0,002 \\
$\begin{array}{l}\text { Soreness or muscle } \\
\text { pain of neck and } \\
\text { shoulders }\end{array}$ & & & & \\
$\begin{array}{l}\text { Muscle pain } \\
\text { during the }\end{array}$ & $32(74,7 \%)$ & $42(58,3 \%)$ & 6,260 & 0,012 \\
$\begin{array}{l}\text { function } \\
\text { Arthralgia tmj }\end{array}$ & $39(54,2 \%)$ & $12(16,6 \%)$ & 13,09 & $<0,001$ \\
$\begin{array}{l}\text { Difficulty opening } \\
\text { mouth }\end{array}$ & $32(44,4 \%)$ & $10(13,8 \%)$ & 16,268 & $<0,001$ \\
$\begin{array}{l}\text { Temporal } \\
\text { headache }\end{array}$ & $30(41,6 \%)$ & $26(36,1 \%)$ & 0,467 & 0,494 \\
Tinnitus & $40(55,5 \%)$ & $18(25 \%)$ & 13,972 & $<0,001$ \\
\hline
\end{tabular}

Pain during muscle palpation was the most commonly reported symptom in SS patients, due to a remarkable muscular contracture. For almost all muscles examined, pain reported was significantly higher in the study group than in the control one ( $p \leq$ $0,05)$. No significant differences between the two groups was found for medial and posterior temporal muscles and lateral pterygoid muscles (Table 7).

\section{SS signs}

At the clinical examination, $91,7 \%$ of SS have at least one oral sign respect to $75 \%$ of controls and this difference is statistically significant $\left(X^{2}=7,20, p=\right.$ 0,007 ) (Table 8).

Table 7. Myofascial pain in SS patients and controls

\begin{tabular}{|c|c|c|c|c|}
\hline Pain on muscle palpation & SS & Controls & $\mathrm{X}^{2}$ & $\begin{array}{l}p \\
\text { Value }\end{array}$ \\
\hline Anterior temporalis muscle & $35(48,61 \%)$ & $18(25 \%)$ & 8,628 & 0,003 \\
\hline Medial temporalis muscle & $12(16,66 \%)$ & $10(13,88 \%)$ & 0,214 & 0,643 \\
\hline Posterior temporalis muscle & $21(29,16 \%)$ & $15(20,83 \%)$ & 1,333 & 0,248 \\
\hline $\begin{array}{l}\text { Sternocleidomastoid } \\
\text { muscles-sternal head }\end{array}$ & $31(43,05 \%)$ & $15(20,83 \%)$ & 8,177 & 0,004 \\
\hline $\begin{array}{l}\text { Sternocleidomastoid } \\
\text { muscles - clavicular head }\end{array}$ & $19(26,38 \%)$ & $4(5,55 \%)$ & 11,642 & $<0,001$ \\
\hline $\begin{array}{l}\text { Digastric muscle-anterior } \\
\text { belly } \\
\text { Digastric muscle-posterior } \\
\text { belly }\end{array}$ & $\begin{array}{l}18(25 \%) \\
23(31,94 \%)\end{array}$ & $\begin{array}{l}5(6,94 \%) \\
5(6,94 \%)\end{array}$ & $\begin{array}{c}8,744 \\
14,364\end{array}$ & $\begin{array}{l}0,003 \\
<0,001\end{array}$ \\
\hline Superficial masseter muscles & $41(56,94 \%)$ & $21(29,16 \%)$ & 11,329 & $<0,001$ \\
\hline Deep masseter muscles & $34(47,22 \%)$ & $11(15,27 \%)$ & 17,098 & $<0,001$ \\
\hline Medial pterygoid muscles & $40(55,55 \%)$ & $23(31,94 \%)$ & 8,155 & 0,004 \\
\hline Lateral pterygoid muscles & $56(77,8 \%)$ & $54(75 \%)$ & 0,154 & 0,694 \\
\hline Mylohyoid muscles & $26(36,11 \%)$ & $3(4,16 \%)$ & 22,841 & $<0,001$ \\
\hline
\end{tabular}

Table 8. Oral signs for SS and controls.

\begin{tabular}{|c|c|c|c|c|}
\hline Oral signs & SS & Controls & Test & $p$ Value \\
\hline Tooth decay & $41(56,94 \%)$ & $29(40,28 \%)$ & $\mathrm{X}^{2}=4,003$ & 0,045 \\
\hline $\begin{array}{l}\text { Gengivitis and } \\
\text { Periodontal changes }\end{array}$ & $54(75,0 \%)$ & $32(44,44 \%)$ & $X^{2}=13,972$ & $<0,001$ \\
\hline $\begin{array}{l}\text { Atrophia of filiform } \\
\text { papilla }\end{array}$ & $12(16,67 \%)$ & $2(2,78 \%)$ & $X^{2}=7,912$ & 0,004 \\
\hline Angular cheilitis & $12(16,67 \%)$ & $2(2,78 \%)$ & $X^{2}=23,591$ & $<0,001$ \\
\hline Candidiasis & $9(12,5 \%)$ & 0 & $\begin{array}{l}\text { Fisher exact } \\
\text { test }\end{array}$ & 0,001 \\
\hline $\begin{array}{l}\text { Oral ulcerations } \\
\text { (small aphthae) }\end{array}$ & $15(20,83 \%)$ & $12(16,67 \%)$ & $X^{2}=0,410$ & 0,521 \\
\hline
\end{tabular}

Also the salivary flow measurements showed high statistical significance between the two groups (Unpaired test, $p<0.0001$ ). Mean and SD are: $0.458 \pm$ 0.395 for SS and $0.797 \pm 0.571$ for control group (fig.1).

\section{TMD Signs}

Values for restricted movements (calculated by T-student test, two-tailed) were not statistically significant different between SS and controls patients. Measurement data (mean $\pm \mathrm{SD}$ ) related to movements were reported below: the maximal mouth opening was $43,43 \mathrm{~mm} \pm 6,12 \mathrm{~mm}$ in SS patients and $42,64 \mathrm{~mm}$ 
$\pm 5,72 \mathrm{~mm}$ in the control group $(p=0,424)$, the right lateral excursion was $6,93 \mathrm{~mm} \pm 2,64 \mathrm{~mm}$ in SS patients and $7,28 \mathrm{~mm} \pm 2,42 \mathrm{~mm}$ in the controls $(p=$ $0,413)$, the left lateral excursion was $7,36 \mathrm{~mm} \pm 2,75$ $\mathrm{mm}$ in SS patients and $6,83 \mathrm{~mm} \pm 2,54 \mathrm{~mm}$ in the controls ( $p=0.233$ ), the protrusion was $4,92 \mathrm{~mm} \pm 2,77$ $\mathrm{mm}$ in SS patients and 4,54 $\mathrm{mm} \pm 2,38 \mathrm{~mm}(p=0.385)$. The only exception was the endfeel $(63,9 \%$ in SS patients and $44,4 \%$ in controls). This value showed a statistically significant difference among the groups $\left(X^{2}=5.482 ; p=0.019\right)$ (fig.2; fig.3).

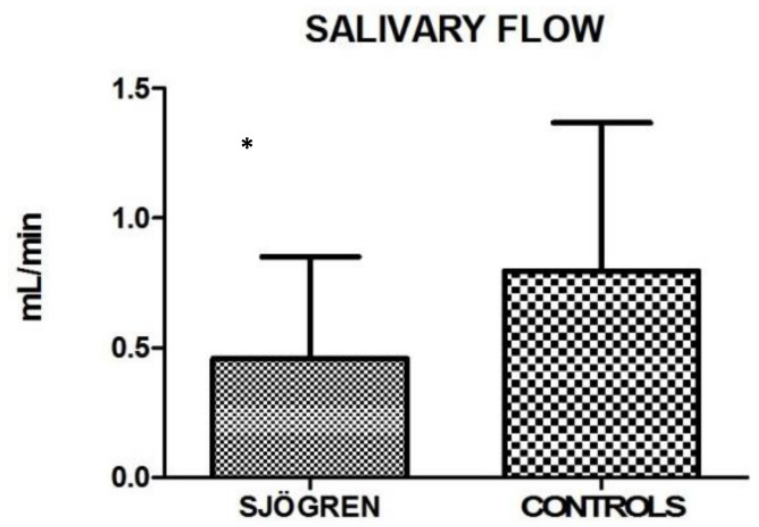

Figure 1. Mean values \pm SD of SS and control group. SS patients show a reduced salivary flow.

The prevalence of parafunctional habits was significantly higher in patients with SS disease than in the control group: $30,56 \%$ of SS reported bruxism versus $15,28 \%$ of controls $\left(X^{2}=4.757, p=0.029\right)$; also teeth clenching was more frequent in SS group than control one $\left(X^{2}=4.05, p=0,044\right)$. As regard parafunctional signs, only the wear facets were found in study group with a significant difference respect to controls $\left(\chi^{2}=4.012, p=0.045\right)$ (Table 9).

Table 9. Parafunctional habits and signs in SS patients and controls.

\begin{tabular}{lllll}
\hline $\begin{array}{l}\text { Parafunctional habits } \\
\text { and signs }\end{array}$ & SS & Controls & $\mathbf{X}^{\mathbf{2}}$ & $\boldsymbol{p}$ Value \\
\hline Teeth clenching & $38(52,78 \%)$ & $26(36,11 \%)$ & 4,05 & 0,044 \\
Bruxism & $22(30,56 \%)$ & $11(15,28 \%)$ & 4,757 & 0,029 \\
Wear facets & $44(61,11 \%)$ & $32(44,4 \%)$ & 4,012 & 0,045 \\
Irregular lingual edges & $31(43,56 \%)$ & $29(40,28 \%)$ & 0,114 & 0,735 \\
Buccal occlusal line & $19(26,39 \%)$ & $17(23,61 \%)$ & 0,148 & 0,701 \\
\hline
\end{tabular}

The clicks and crepitus sounds of the TMJ during mandibular opening and closing movements were not statistically significant different between the study and control groups $(p<0,05)$, except the "pop noise", higher in SS than in controls (Fisher exact test, $p=$ 0.043). In addition, the crepitation of SS patients was higher compared to the controls, but there was not a statistically significant difference between the two groups (Table 10).
Table 10. Joint sounds in SS patients and controls.

\begin{tabular}{lllll}
\hline Joint sounds & SS & Controls & Test & $p$ Value \\
\hline $\begin{array}{l}\text { Click during } \\
\text { opening }\end{array}$ & $22(30,56 \%)$ & $25(34,72 \%)$ & $X^{2} 0,284$ & 0,593 \\
$\begin{array}{l}\text { Click during } \\
\text { closing }\end{array}$ & $14(19,44 \%)$ & $12(16,67 \%)$ & $X^{2} 0,187$ & 0,664 \\
$\begin{array}{l}\text { Pop noise } \\
\text { Crepitation }\end{array}$ & $18(25 \%)$ & $9(12,5 \%)$ & $\begin{array}{l}\text { Fisher } \\
\text { exact test }\end{array}$ & 0,043 \\
\hline
\end{tabular}

A

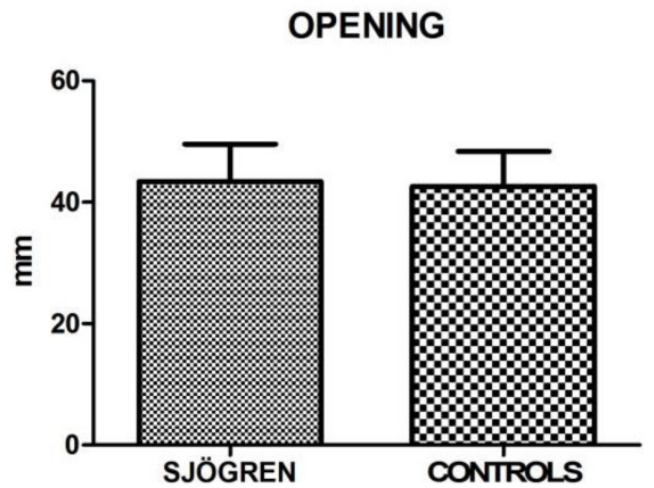

B

\section{PROTRUSION}

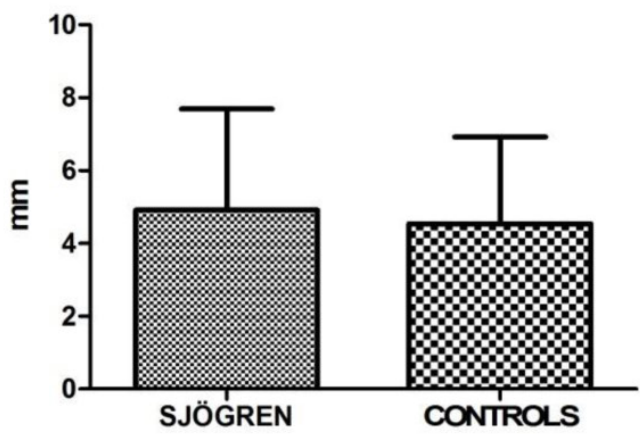

C

ENDFEEL

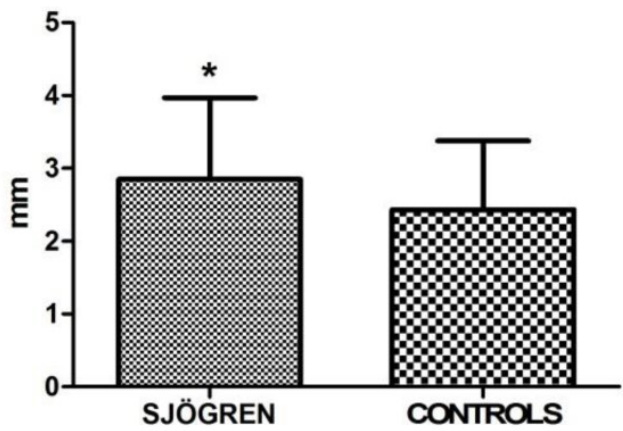

Figure 2 A, B, C. Mean values \pm SD of SS and control group. Movement width evaluation shows no statistically significant differences, except for endfeel.

As regard the alterations in the mouth opening pathway, deviation and deflection, only the deflection was significantly higher in SS patients than in the controls $\left(\chi^{2}=5,402 p=0,020\right)$ (Table 11). 
A
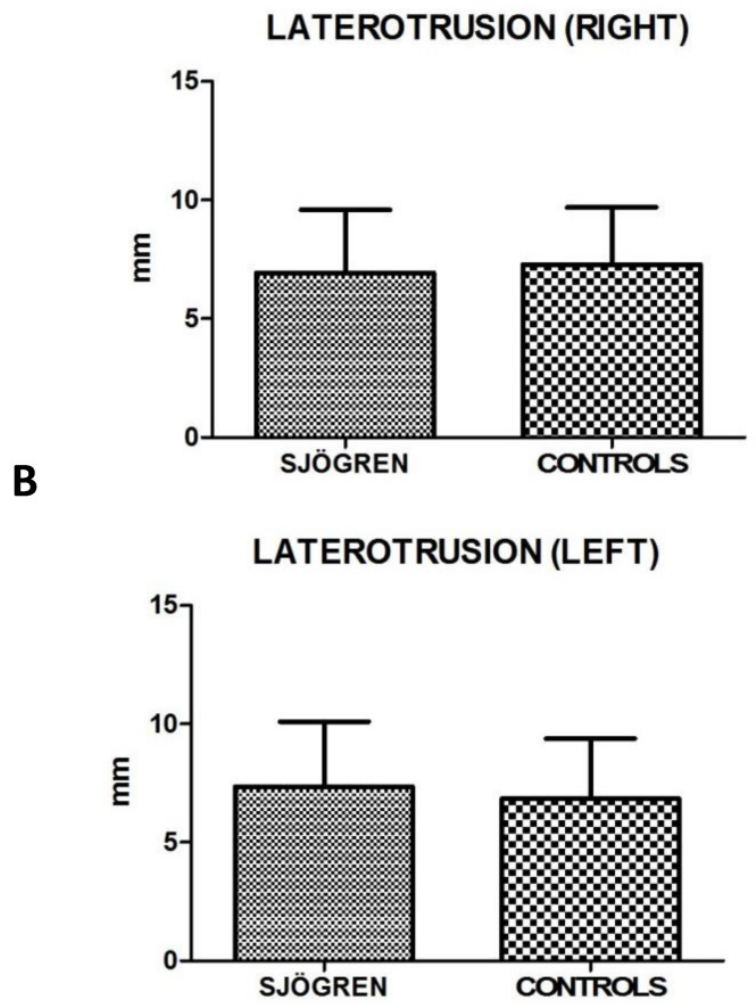

Figure 3 A, B. Mean values \pm SD of SS and control group. Laterotrusion size evaluation is quite overlapping, with no statistically significant differences.

Table 11. Opening derangement in SS patients and controls.

\begin{tabular}{lllll}
\hline $\begin{array}{l}\text { Opening } \\
\text { Derangement }\end{array}$ & SS & Controls & $x^{2}$ & $p$ Value \\
\hline Deviation & $36(50,0 \%)$ & $43(59,72 \%)$ & 1,374 & 0,241 \\
Deflection & $13(18,05 \%)$ & $4(5,5 \%)$ & 5,402 & 0,020 \\
\hline
\end{tabular}

\section{Discussion}

The present study analyzed the prevalence of oral manifestation and TMD symptoms and signs in SS patients compared with healthy controls, with a cohort size larger than other studies investigating SS and TMD (72 SS versus 1 in Burges [40], 21 in List et al. [22], 23 in Keris et al. [41].

About sociodemographic characteristics, education, primary, secondary and high school have a similar prevalence in SS group, while among controls there are more graduates (high and academic). Housewives were equally represented in both SS patients and controls, while public employees were most represented in control group (Table 1). According to Meijer et al., these patients have a faulty socio-economic status, resulting in lower employment rates as compared with the general population [42]. Local and systemic conditions due to the syndrome can worsen quality of life and psychological status in SS patients, from the most common findings such as pain, asthenia, ocular and oral dryness, to the awareness of an increased risk of developing malignant neoplasms. Particularly non-Hodgkin B cell lymphoma may occur with an incidence 16 times higher than in general population [43] and some patients regularly take antidepressants $(4.2 \%)$ and benzodiazepines (5.6\%). Also rheumatological conditions can have a serious impact on patients, so they may be limited in their activities and their participation in society.

Another interesting finding collected is the frequent use of antacid medications in SS (61.1\%) versus in controls $(4.2 \%)\left(\chi^{2}=53.096, p<0.001\right)$, which is due both to the complications of the disease and to the somatization of psychological aspects. Among the main drugs used in the treatment there are: corticosteroids (69.4\%), methotrexate (31.9\%), hydroxychloroquine (40.3\%), pilocarpine (29.2\%). Thirty-six $(50.0 \%)$ of SS patients recruited have been taking saliva and/or tear supplements, providing moisture and comfort from dry mouth and/or dry eyes.

Mucosal symptoms and signs were evaluated in SS and control group, showing statistically significant findings.

Xerostomia was complained by $91.7 \%$ of SS patients recruited for the present study, versus 19,4\% of the controls, thus overlapping this finding to that reported by Soto-Rojas et al. [44] (98\% of SS patients) and by Olate et al. [45], who detected features of sicca syndrome in $100 \%$ of SS patients. This remarkable symptom is confirmed by the salivary test, with a significantly reduced salivary flow in $26.4 \%$ of patients. In addition, the hyposalivation may be responsible for dysgeusia $(31,9 \%$ in SS patients against $4,2 \%$ of the controls) and dysphagia, complained only by subjects with SS $(13,9 \%)$.

The main oral signs reported in SS patients are: dental caries $(56,9 \%)$, gingivitis with swollen and reddened gums (75\%), exfoliative and angular cheilitis $(16,7 \%)$ with dry, cracked and pelling lips. These data show a similar prevalence if compared with findings by Błochowiak et al. [13], who recorded cheilitis in $18,2 \%$ of SS patients. About gingivitis and periodontal conditions, Antoniazzi et al. [46] found that the SS patient group presented significantly higher percentage of gingivitis than controls. On the other side, Pedersen et al. [47] and Boutsi et al. [48] both showed that SS patients did not have a significantly higher periodontal disease if compared to healthy controls.

In this study, atrophy of filiform papillae $(16,7$ $\%)$, stomatitis as well as candidiasis $(12,5 \%)$, nonspecific ulcerations $(20,8 \%)$ were detected. The prevalence of this findings is higher in Ergun et al. 
[49]: atrophy of filiform papilla and oral ulcerations affected $48,65 \%$ and $35,13 \%$ of patients, respectively.

About TMD symptoms, most of them show statistically significant prevalence. They include pain in the pre-auricular area $(54,2 \%)$, tinnitus and ear pain $(55,5 \%)$, neck and shoulders pain or stiffness $(77,7 \%)$, subjective weakness $(27,7 \%)$ and pain during movement of masticatory muscles $(44,4 \%)$, temporal headaches $(41,6 \%)$, a feeling of locked during opening mouth $(44,4 \%)$. All these were proved to be more recurring findings in the study group than in the control one.

The most common symptom in patients with SS was myalgia during palpation and arthralgia, as reported by Y. Keris et al. [41], having considered the posterior, middle and anterior part of the temporalis muscle, masseter muscle, lateral and medial pterygoid muscles.

The present study additionally evaluated the following muscles: sternocleidomastoid, digastric, mylohyoid.

Symptoms related to muscle palpation indicate muscular contracture in SS patients, especially in superficial $\left(56.91 \%, \chi^{2}=11.329, p<0.001\right)$ and deep masseter $\left(47.22 \%, \chi^{2}=17.098, p<0.001\right)$. Values recorded for medial and posterior temporalis muscle and lateral pterygoid muscle are not statistically significant, showing a similar distribution in both groups.

Restrictions on mandibular movements were not statistically significant respect to control group. Only endfeel $\left(\chi^{2}=5,482, p=0,019\right)$ was significant. The latter supports the data obtained during muscles palpation, translating the subjective complaint into an objective and numeric value.

The results about joint sounds during mandibular movements do not deviate from Keris [41], except for a significant prevalence in the SS group regarding to pop noise. Moreover, they differ in a work by List [22], that showed $57 \%$ of SS patients had clicking.

Parafunctional habits, likely related to stress, showed a low prevalence of clenching $\left(\chi^{2}=4.05 p=\right.$ $0.044)$, wear facets $\left(X^{2}=4.012, p=0.045\right)$, and bruxism $\left(X^{2}=4.757, p=0.029\right)$.

As regards alterations of the mandibular kinematic, only the deflection is statistically significant $\left(18,05 \%\right.$ of SS versus $5,5 \%$ of controls; $\chi^{2}=$ $5.402, p=0.020)$.

List and collaborators [22] found that 29\% of patients with SS exhibited arthritis or arthralgia at the TMJ. In addition, the pain in the joint palpitations was higher in the SS patients than the controls, but there is no statistically significant difference between the two groups $(p>0.05)$. This finding differs from what emerged from the present work $(54,4 \%$ of SS patients versus $25 \%$ of controls; $\chi^{2}=12,8, p<0.001$ ).

\section{Conclusion}

From the analysis of the data collected, a statistically significant increase of oral manifestations was detected in SS patients when compared to a control healthy group. Particularly, xerostomia and all its consequences such as dysgeusia, dysphagia, dental caries, gingivitis, angular cheilitis and candidiasis were found to be more frequent in patients with SS.

In addition to oral manifestations and rheumatological implications, Sjögren's syndrome seems to play a role in TMD especially as regards to muscular contracture (high prevalence of myalgia to muscle palpation and positive endfeel) and joint disease (greater pop-noise and deflection during mandibular opening), causing an increase in orofacial pain and an altered chewing function.

\section{Abbreviations}

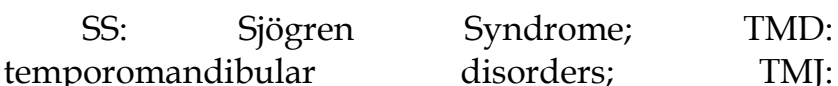
temporomandibular joint; RDC/TMD: research diagnostic criteria for temporomandibular disorders; TMDs: symptoms of temporomandibular disorders; OD: opening derangement; BRUX: bruxism; TMJs: sounds of temporomandibular joint; MP: myofascial pain; RM: restricted movements; AECG: American-European Consensus Group; VAS: visual analogic scale.

\section{Authors' Contribution}

\author{
Study Design A \\ Data Collection B \\ Statistical Analysis C \\ Data Interpretation D \\ Manuscript Preparation E \\ Literature Search F \\ ADE Vito Crincoli \\ CD Mariasevera Di Comite \\ BF Mariateresa Guerrieri \\ EF Rossana Patricia Rotolo \\ F Luisa Limongelli \\ F Angela Tempesta \\ A Florenzo Iannone \\ BF Angela Rinaldi \\ A Giovanni Lapadula \\ A Gianfranco Favia
}

\section{Competing Interests}

The authors have declared that no competing interest exists. 


\section{References}

1. Seror R, Theander E, Bootsma H, Bowman SJ, Tzioufas A, Gottenberg JE, Ramos-Casals M, Dörner T, Ravaud P, Mariette X, Vitali C. Outcome measures for primary Sjögren's syndrome: A comprehensive review. J Autoimmun. 2014; 51: 51-6.

2. Fox RI. Sjögren's syndrome. The Lancet. 2005; 366 (9482): 321-31.

3. Baldini C, Talarico R, Tzioufas AG, Bombardieri S. Classification criteria for Sjogren's syndrome: A critical review. J Autoimmun. 2012; 39: 9-14.

4. Vitali C, Bombardieri S, Jonsson R, Moutsopoulos HM, Alexander EL, Carsons SE, Daniels TE, Fox PC, Fox RI, Kassan SS, Pillemer SR, Talal N, Weisman MH; European Study Group on Classification Criteria for Sjögren's Syndrome. Classification criteria for Sjögren's syndrome: a revised version of the European criteria proposed by the American-European Consensus Group. Ann Rheum Dis. 2002; 61(6): 554-8.

5. Mavragani CP, Moutsopoulos HM. The geoepidemiology of Sjögren's syndrome. Autoimmunity Reviews. 2010; 9: A305-A310.

6. Patel R, Shahane A. The epidemiology of Sjögren's syndrome. Clin Epidemiol. 2014; 6: 247-55.

7. Nezos A, Mavragani CP. Contribution of Genetic Factors to Sjögren's Syndrome and Sjögren's Syndrome Related Lymphomagenesis. J Immunol Res; 2015, Article ID 754825, 12 pages.

8. Rasmussen $\mathrm{A}$, Ice JA, $\mathrm{Li} \mathrm{H}$, Grundahl $\mathrm{K}$ et al. Comparison of the American-European Consensus Group Sjogren's syndrome classification criteria to newly proposed American College of Rheumatology criteria in a large, carefully characterized sicca cohort. Ann Rheum Dis. 2013; 73: 1-2.

9. Mavragani CP, Tzioufas AG, Moutsopoulos HM. Sjögren's syndrome: autoantibodies to cellular antigens. Clinical and molecular aspects. Int Arch Allergy Immunol. 2000; 123(1): 46-57.

10. Manoussakis MN, Kapsogeorgou EK. The role of intrinsic epithelial activation in the pathogenesis of Sjögren's syndrome. J Autoimmun. 2010; 35(3): 219-24.

11. Gonzàlez S, Sung H, Sepùlveda D, Gonzàles M, Molina C. Oral manifestations and their treatment in Sjogren's Syndrome. Oral Dis. 2014; 20(2): 153-61.

12. Aoun G, Nasseh I, Berberi A. Evaluation of the oral component of Sjögren's syndrome: An overview. J Int Soc Prev Community Dent. 2016; 6(4): 278-84.

13. Błochowiak K, Olewicz-Gawlik A, Polańska A, Nowak-Gabryel M,Kocięcki J, Witmanowski H,Sokalski J. Oral mucosal manifestations in primary and secondary Sjögren syndrome and dry mouth syndrome. Postepy Dermatol Alergol. 2016; 33(1): 23-7.

14. Mignogna MD, Fedele S, Lo Russo L, Lo Muzio L, Wolff A. Sjögren's syndrome: the diagnostic potential of early oral manifestations preceding hyposalivation/xerostomia. J Oral Pathol Med. 2005; 34(1): 1-6.

15. Papiris SA, Maniati M, Constantopoulos SH, Roussos C, Moutspoulos HM, Skopouli FN. Lung involvement in primary Sjogren's syndrome is mainly related to the small airway disease. Ann Rheum Dis. 1999; 58(1): 61-4.

16. Mori K, Iijima M, Koike H, Hattori N, Tanaka F, Watanabe H, Katsuno M, Fujita A, Aiba I, Ogata A, Saito T, Asakura K, Yoshida M, Hirayama M, Sobue G. The wide spectrum of clinical manifestations in Sjogren's syndrome-associated neuropathy. Brain. 2005; 128(Pt 11): 2518-34.

17. Dong L, Chen Y, Masaki Y, Okazaki T, Umehara H. Possible Mechanisms of Lymphoma Development in Sjögren's Syndrome. Curr Immunol Rev. 2013; 9(1): 13-22.

18. Priori R, Iannuccelli C, Alessandri C, Modesti M, Antonazzo B, Di Lollo AC, Valesini G, Di Franco M. Fatigue in Sjögren's syndrome: relationship with fibromyalgia, clinical and biological features. Clin Exp Rheumatol. 2010; 28 (6 Suppl 63): S82-6.

19. Ienopoli S, Carsons SE. Extraglandular Manifestations of Primary Sjögren's Syndrome. Oral Maxillofac Sur Clin North Am. 2014; 26(1): 91-9.

20. Fauchais AL, Ouattara B, Gondran G, Lalloué F, Petit D, Ly K, Lambert M, Launay D, Loustaud-Ratti V, Bezanahari H, Liozon E, Hachulla E, Jauberteau MO, Vidal E, Hatron PY. Articular manifestations in primary Sjögren's syndrome: clinical significance and prognosis of 188 patients. Rheumatology (Oxford). 2010; 49(6): 1164-72.

21. Ramos-Casals $M$, Brito-Zerón $P$, Seror $R$, Bootsma $H$, Bowman SJ, Dörner T, Gottenberg JE, Mariette X, Theander E, Bombardieri S, De Vita S, Mandl T, Ng WF, Kruize A, Tzioufas A, Vitali C; EULAR Sjögren Syndrome Task Force. Characterization of systemic disease in primary Sjögren's syndrome: EULAR-SS Task Force recommendations for articular, cutaneous, pulmonary and renal involvements. Rheumatology (Oxford). 2015; 54(12): 2230-8.

22. List T, Stenström B, Lundström I, Dworkin SF. TMD in patients with primary Sjogren syndrome: a comparison with temporomandibular clinic cases and controls. J Orofac Pain. 1999; 13(1): 21-8.

23. Dworkin SF, LeResche L. Research diagnostic criteria for temporomandibular disorders: Review, criteria, examinations and specifications, critique. J. Craniomandib Disord. 1992; 6(4): 301-55.

24. Hopcraft MS, Tan C. Xerostomia: an update for clinicians. Aust Dent J. 2010; 55(3): 238-44.

25. Löfgren CD1, Wickström C, Sonesson M, Lagunas PT, Christersson C. A systematic review of methods to diagnose oral dryness and salivary gland function. BMC Oral Health. 2012; 12: 29.

26. Villa A, Connell CL, Abati S. Diagnosis and management of xerostomia and hyposalivation. Ther Clin Risk Manag. 2014; 11: 45-51.

27. Navazesh M. Methods for collecting saliva. Ann NY Acad Sci. 1993; 694: 72-7.

28. Navazesh M, Kumar SK. Measuring salivary flow. Challenges and opportunities. J Am Dent Assoc. 2008; 139 Suppl: 35S-40S.
29. Mott AE, Grushka M, Sessle BJ. Diagnosis and management of taste disorders and burning mouth syndrome. Dent Clin North Am. 1993; 37(1): 33-71.

30. Gil-Martínez A, Grande-Alonso M, López-de-Uralde-Villanueva I. LòpezLòpez A, Fernàndez- Carnero J, La Touche R. Chronic Temporomandibular Disorders: disability, pain intensity and fear of movement. J Headache Pain. 2016; 17(1): 103.

31. Hara K, Shinozaki T, Okada-Ogawa A, Matsukawa Y, Dezawa K, Nakaya Y, Chen JY, Noma N, Oka S, Iwata K, Imamura Y. Headache attributed to temporomandibular disorders and masticatory myofascial pain. J Oral Sci. 2016; 58(2): 195-204.

32. Buergers R, Kleinjung T, Behr M, Vielsmeier V. Is there a link between tinnitus and temporomandibular disorders? J. Prosthet. Dent. 2014; 111(3): 222-227.

33. Fricton J. Myogenous temporomandibular disorders: diagnostic and management considerations. Dent Clin North Am. 2007; 51(1): 61-83.

34. Tecco S, Crincoli V, Di Bisceglie B, Saccucci M, Macrì M, Polimeni A, Festa F. Signs and symptoms of temporomandibular joint disorders in Caucasian children and adolescents. Cranio. 2011; 29(1): 71-79.

35. Lavigne GJ, Khoury S, Abe S, Yamaguchi T, Raphael K. Bruxism physiology and pathology: An overview for clinicians. J. Oral Rehabil. 2008; 35(7): 476-494.

36. Bell WE. Orofacial Pains: Differential Diagnosis. Chicago, USA: 2nd ed. YearBook Medical Publishers Inc.; 1979.

37. Sener S, Akgunlu F. Correlation between the Condyle Position and Intra-Extraarticular Clinical Findings of Temporomandibular Dysfunction. Eur J Dent. 2011; 5(3): 354-360.

38. Agerberg G. Maximal mandibular movements in young men and women. Sven Tandlak Tidskr. 1974; 67: 81-100.

39. Solberg W. Occlusion-related pathosis and its clinical evaluation. In: Clinical Dentistry. New York, USA: Harper \& Row Publishers; 1976: 1-29.

40. Burges JA. Temporomandibular joint arthritis in a patient with Sjogren's Syndrome: A case report. Cranio. 1989; 7(4): 351-5.

41. Yildizer Keriş E, Yaman SD, Demiră̆ MD, Haznedaroğlu Ş. Temporomandibular joint findings in patients with rheumatoid arthritis, ankylosing spondylitis, and primary Sjogren syndrome. J Investing Clin Dent. 2017; 8(4):1-7.

42. Meijer JM, Meiners PM, Huddleston Slater JJR, Spijkervet FKL, Kallenberg CGM, Vissink A, Bootsma H. Health-related quality of life, employment and disability in patients with Sjögren's syndrome. Rheumatology. 2009; 48(9): 1077-82.

43. Theander E, Henriksson G, Ljungberg O, Mandl T, Manthorpe R, Jacobsson LTH. Lymphoma and other malignancies in primary Sjögren's syndrome: a cohort study on cancer incidence and lymphoma predictors. Ann Rheum Dis. 2006; 65(6): 796-803.

44. Soto-Rojas AE, Kraus A. The Oral Side of Sjögren Syndrome. Diagnosis and Treatment. A Review. Arch Med Res. 2002; 33(2): 95-106.

45. Olate S, Muñoz D, Neumann S, Pozzer L, Cavalieri-Pereira L, de Moraes M. A descriptive study of the oral status in subjects with Sjögren's syndrome. Int J Clin Exp Med. 2014; 7(4): 1140-4.

46. Antoniazzi RP, Miranda LA, Zanatta FB, Islabão AG, Gustafsson A, Chiapinotto GA, Oppermann RV. Periodontal conditions of individuals with Sjögren's syndrome. J Periodontol. 2009; 80(3): 429-35.

47. Pedersen AM, Bardow A, Nauntofte B. Salivary changes and dental caries as potential oral markers of autoimmune salivary gland dysfunction in primary Sjögren's syndrome. BMC Clin Pathol. 2005; 5(1): 4.

48. Boutsi EA, Paikos S, Dafni UG, Moutsopoulos HM, Skopouli FN. Dental and periodontal status of Sjogren's syndrome. J Clin Periodontol. 2000; 27(4): $231-5$.

49. Ergun S, Çekici A, Topcuoglu N, Migliari DA, Külekçi G, Tanyeri H, Isik G. Oral status and Candida colonization in patients with Sjögren's Syndrome. Med Oral Patol Oral Cir Bucal. 2010; 15(2): e310-5. 